\section{KISS1 and KISS1R expression in the human and rat carotid body and superior cervical ganglion}

\author{
A. Porzionato, ${ }^{1}$ G. Fenu, ${ }^{2}$ M. Rucinski, ${ }^{3}$ \\ V. Macchi, ${ }^{1}$ A. Montella, ${ }^{2}$ \\ L.K. Malendowicz, ${ }^{3}$ R. De Caro ${ }^{1}$ \\ 'Section of Anatomy, Department \\ of Human Anatomy and Physiology, \\ University of Padova, Italy; \\ 2Department of Biomedical Sciences, \\ University of Sassari, Sassari, Italy; \\ ${ }^{3}$ Department of Histology and \\ Embryology, Poznan University \\ of Medical Sciences, Poznan, Poland
}

\section{Abstract \\ KISS1 and its receptor, KISS1R, have both} been found to be expressed in central nervous system, but few data are present in the literature about their distribution in peripheral nervous structures. Thus, the aim of the present study was to investigate, through immunohistochemistry, the expression and distribution of KISS1 and KISS1R in the rat and human carotid bodies and superior cervical ganglia, also with particular reference to the different cellular populations. Materials consisted of carotid bodies and superior cervical ganglia were obtained at autopsy from 10 adult subjects and sampled from 10 adult Sprague-Dawley rats. Immunohistochemistry revealed diffuse expression of KISS1 and KISS1R in type I cells of both human and rat carotid bodies, whereas type II cells were negative. In both human and rat superior cervical ganglia positive anti-KISSI and -KISS1R immunostainings were also selectively found in ganglion cells, satellite cells being negative. Endothelial cells also showed moderate immunostaining for both KISS1 and KISS1R. The expression of both kisspeptins and kisspeptin receptors in glomic type I cells and sympathetic ganglion cells supports a modulatory role of KISS1 on peripheral chemoreception and sympathetic function. Moreover, local changes in blood flow have been considered to be involved in carotid body chemoreceptor discharge and kisspeptins and kisspeptin receptors have also been found in the endothelial cells. As a consequence, a possible role of kisspeptins in the regulation of carotid body blood flow and, indirectly, in chemoreceptor discharge may also be hypothesized.

\section{Introduction}

The KISS1 gene was originally identified through a differential expression approach showing up regulation of its expression in tumor cells which had lost their potential to metastize. ${ }^{1-3}$ It encodes for a 145 amino acid precursor, which can be cleaved into a 54 amino acid protein, originally called metastin, or shorter 14, 13 and 10 amino acid peptides, which share a common C-terminal amidation site. With the term of kisspeptins are collectively named all the peptides cleaved from the precursor hormone. The larger protein shows some variability among species whereas the $C$ terminal 10 amino acid sequence is well conserved. ${ }^{1,46}$

The kisspeptin receptor, now called KISS1R in humans and Kiss1r in rodents, ${ }^{7}$ was initially discovered in rats in 1999 as an orphan G protein-coupled membrane receptor named GPR54, ${ }^{8}$ in 2001 kisspeptins being identified as its natural ligands. ${ }^{4-6,9}$ Its gene shares modest homology with the gene coding for the galanin receptor 2 , although kisspeptins do not bind the above galanin receptor. ${ }^{8}$

Kisspeptins play a crucial role in the control of puberty onset and reproductive function. Apart from central nervous system, KISS1 and KISS1R have both been found to be widely expressed in many other tissues such as the pituitary, gonads, placenta, pancreas, liver, intestines and vessels. ${ }^{1,5,6,10,11}$ As it concerns the peripheral nervous system, both KISS1 and KISS1R have recently been found to be expressed in rat dorsal root ganglion. ${ }^{12}$ To the best of our knowledge, there are no data regarding expression of kisspeptin and kisspeptin receptor in the carotid body and sympathetic ganglia.

The carotid body is the main peripheral arterial chemoreceptor, inducing increases in ventilatory volume and frequency in response to hypoxia, hypercapnia, or reduction of blood $\mathrm{pH}$. It is organized in lobules of cells belonging to two different populations: type I cells, with roundish shape and higher dimensions, and type II cells, with fusiform shape and located at the edges of the clusters. Type I cells represent the real chemoreceptor elements. In response to the various stimuli they release many different neurotransmitters and neuromodulators, ${ }^{13-}$ ${ }^{17}$ which mainly act on the glosso-pharyngeal afferent fibers arising from the petrosal ganglion. However, substances released from type I cells may also act on other components of the carotid body, such as type I cells themselves (through autocrine and paracrin mechanisms), type II cells, vessels, and connective cells. Type II cells show astrocytic markers and play a supportive role, but it has recently been observed that if exposed to prolonged hypoxia
Correspondence: Prof. Raffaele De Caro, Section of Anatomy, Department of Human Anatomy and Physiology, University of Padua, Via A. Gabelli 65, 35121 Padova, Italy.

Tel. +39.049 .8272327 - Fax: +39.049 .8272328 .

E-mail: rdecaro@unipd.it

Key words: Kisspeptin, GPR54, carotid body, superior cervical ganglion.

Conflict of interest: the authors report no conflicts of interest.

Acknowledgement: the authors are grateful to Mrs. Gloria Sarasin and Anna Rambaldo for their skillful technical assistance.

Received for publication: 23 January 2011. Accepted for publication: 22 March 2011.

This work is licensed under a Creative Commons Attribution 3.0 License (by-nc 3.0).

(C) Copyright A. Porzionato et al., 2011

Licensee PAGEPress, Italy

European Journal of Histochemistry 2011; 55:e14 doi:10.4081/ejh.2011.e14

they may also behave as stem cells precursor for type I cells. ${ }^{18}$ The carotid body also shows parasympathetic and sympathetic innervation, the latter mainly from the superior cervical ganglion.

The aim of the present study was therefore to investigate, through immunohistochemistry and real-time RT-PCR, the expression and distribution of KISS1 and KISS1R in the rat and human carotid body and superior cervical ganglia, also with particular reference to the different cellular populations.

\section{Materials and Methods}

\section{Tissue sampling and preparation}

Materials consisted of carotid bodies and superior cervical ganglia obtained at autopsy from 10 adult subjects [ 6 males, 4 females; mean age 46 years, standard deviation (SD) \pm 3.6 ], clinically negative for chronic pulmonary or cardiovascular diseases, and sampled from 10 adult Sprague-Dawley rats. Autopsies were performed between 24 and $30 \mathrm{~h}$ after death.

Sampling from rats was performed soon after sacrifice. Right carotid bifurcations and superior cervical ganglia from humans and rats were fixed in Bouin solution and embedded in paraffin wax. 


\section{Immunohistochemical analysis}

Immunohistochemical examinations were carried out on $3 \mu \mathrm{m}$ thick sections. For antiKISS1R immunohistochemistry, unmasking was performed with $10 \mathrm{mM}$ sodium citrate buffer, $\mathrm{pH} 6.0$, at $90^{\circ} \mathrm{C}$ for $30 \mathrm{~min}$. For antiKISS1 immunohistochemistry, antigen unmasking was not necessary. Sections were incubated in $0.03 \%$ hydrogen peroxide for $10 \mathrm{~min}$ at room temperature, to remove endogenous peroxidase activity, and then in blocking serum ( $0.04 \%$ bovine serum albumin, A2153, SigmaAldrich, Milan, Italy and $0.5 \%$ normal goat serum X0907, Dako Corporation, Carpinteria, $\mathrm{CA}$, USA, in PBS) for 30 min at room temperature. Primary anti-KISS1 antibody (rabbit polyclonal antibody anti-metastin [1-25)/KISS-1 (68-92), Catalog No. H-048-62, Phoenix Pharmaceuticals, Inc., Burlingame, CA, USA] was diluted 1:1500 in blocking serum. Primary anti-KISS1R antibody (rabbit polyclonal antibody anti-AXOR12 (375-398), Catalog No. H048-61, Phoenix Pharmaceuticals, Inc.,) was diluted 1:100 in blocking serum. Both antibodies were incubated overnight at $4^{\circ} \mathrm{C}$. Sections were then washed three times for $5 \mathrm{~min}$ in PBS. Sections were revealed with anti-rabbit serum $\left(\right.$ DAKO$^{\circledR}$ EnVision + TM Peroxidase, Rabbit, Dako Corporation) for $30 \mathrm{~min}$ at room temperature. Finally, sections were developed in 3,3'-diaminobenzidine (DAB, SigmaAldrich) and counterstained with hematoxylin. Negative controls were performed by omission of primary antibody and absorption tests. Immunoreactions detected in human placenta and rat brain were used as positive controls.

The percentages of type I and II positive cells were evaluated on fields of $180 \times 134 \mu \mathrm{m}$. Five sections and 3 fields per section were examined. In rat and human carotid bodies, about 40 and 25-30 type I cells were counted for each field, respectively. The mean percentages of positive cells were calculated for each case and for the entire series.

\section{Statistics}

Percentages obtained were compared with Mann-Whitney test. A P value of 0.05 was considered significant.

\section{Results}

Immunohistochemistry revealed diffuse expression of kisspeptins and receptor in type I cells of both human and rat carotid bodies. Immunostained cells were distributed both in the centre and in the periphery of the lobules. Conversely, no kisspeptins or receptor immunostainings were observed in type II cells (Figure 1). Endothelial cells of some vessels also showed moderate immunostaining for both KISS1 and KISS1R.

In both human and rat superior cervical ganglia positive anti-KISS1 and -KISS1R immunostainings were selectively found in ganglion cells. Satellite cells were negative or only showed weak reaction (Figure 2). Glomic and ganglion cell immunostainings were eliminated when preabsorbed antiserum was used or primary antibodies were omitted.
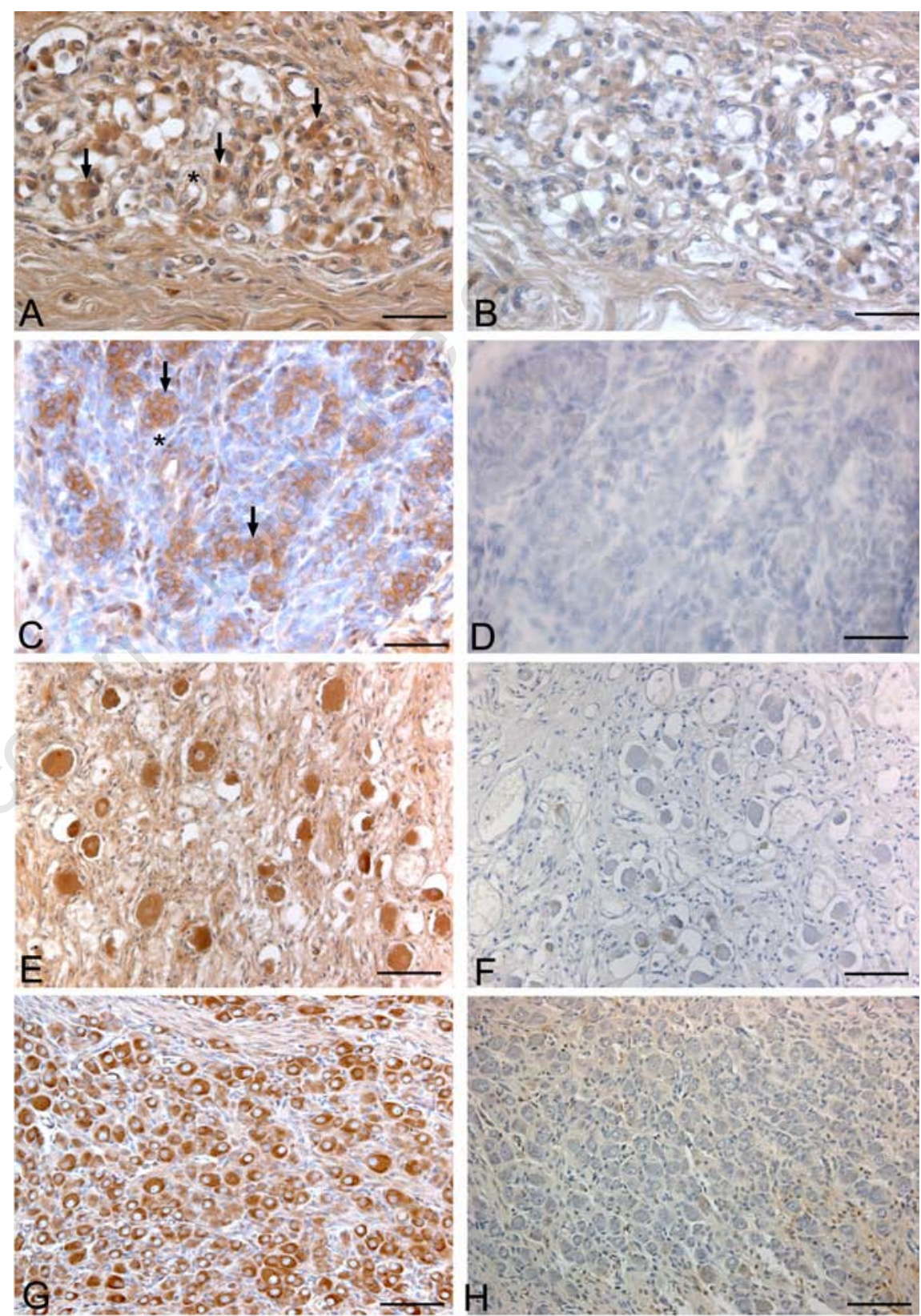

Figure 1. Anti-KISS1 immunohistochemistry in human $(\mathrm{A}, \mathrm{B}, \mathrm{E}, \mathrm{F})$ and rat $(\mathrm{C}, \mathrm{D}, \mathrm{G}, \mathrm{H})$ carotid bodies (A-D) and superior cervical ganglia (E-H), showing selective positivity of glomic type I cells (arrows) and ganglionic cells, immunostaining being largely eliminated in negative controls $(\mathrm{B}, \mathrm{D}, \mathrm{F}, \mathrm{H})$. Note also negativity of type II cells (asterisks) in the carotid body and of satellite cells in the superior cervical ganglia. Scale bars: A-D, $37.5 \mu \mathrm{m}$; E-H, $75 \mu \mathrm{m}$. 
discharge. ${ }^{13-15,19,20}$ Our findings about expression of both KISS1 and KISS1R in type I cells, which represent the real chemoreceptive element of the carotid body, support a modulatory role of KISS1 on peripheral chemoreception. Kisspeptins have been found to directly stimulate excitability of neurons, such as the granule cells of the dentate gyrus, ${ }^{21}$ and to modulate the release of other peptides, such as in hypophysis ${ }^{22}$ and islets of Langherans. ${ }^{23,24}$ Thus, also in the carotid body kisspeptins could act on excitability of type I cells and/or on their release of peptide neuromodulators. Further functional studies will be necessary to clarify the effects of kisspeptins on chemosensory process in glomic cells. Kisspeptin receptor probably preferentially bind peptides locally released in the carotid body but circulating factors have also been reported to act on carotid body type I cells, and possible actions by blood-borne kisspeptins may not be excluded.

The possible role of kisspeptins in the cardiovascular system has also recently been considered. The carotid body is the structure in the body with the highest blood flow (about 1400 or $2000 \mathrm{~mL} / 100 \mathrm{~g} / \mathrm{min}$ in the cat, depending on the technique for determination of tissue blood flow), ${ }^{25,26}$ and local changes in blood flow have been considered to be involved in carotid body chemoreceptor discharge. ${ }^{20,27,28}$ KISS1R and KISS1 have been found to be expressed in the endothelial cells of the aorta, coronary artery and umbilical vein and kisspeptins have been demonstrated to show potent vasoconstrictor action. ${ }^{10}$ In the present work anti-KISS1 and - KISS1R immunoreactions were also found in endothelial cells of some vessels, as a consequence a possible role of kisspeptins in the regulation of carotid body blood flow and, indirectly, in chemoreceptor discharge may be hypothesized.

Kisspeptins could also show trophic actions on glomic cells. In the pre- and postnatal periods the carotid body undergoes structural changes, mediated by trophic factors, including carotid body volume increase, proliferation of type I, type II, endothelial and Schwann cells lining peripheral nerve fibers and increased number of synapses between type I and II cells. ${ }^{15,29}$ Moreover, environmental stimuli (for instance, hypoxic, hyperoxic or inflammatory noxae) may also cause a series of morphological, cellular and biochemical changes. ${ }^{29-34}$ For instance, chronic hypoxia has been shown to increase $\mathrm{O}_{2}$ sensitivity in the carotid body through changes in molecular chemoreceptors, ion channels and neurochemicals. ${ }^{35-37}$ The above changes are mediated by a wide series of trophic factors. It may also be hypothesized that kisspeptins released by type I cells may modulate the expression and effects of trophic factors in the carotid body. For instance, kisspeptins have been found to increase BDNF expression in hippocampal slice cultures ${ }^{38}$ and this growth factor has been identified in type I cells and nerve fibers of rat carotid body. ${ }^{15,39,40}$

In the literature, KISS1 and KISS1R have been found to be expressed in the dorsal root ganglia and to be upregulated after intraarticular injection of the complete Freund's adjuvant, suggest- ing possible involvement in chronic inflammatory pain. ${ }^{12}$ In the present work, expressions of both KISS1 and KISS1R were found in ganglion cells of the human and rat superior cervical ganglia. Thus, it may be hypothesized a role of kisspeptins also in the modulation of the sympathetic function, probably mainly through autocrine or paracrine mechanisms.
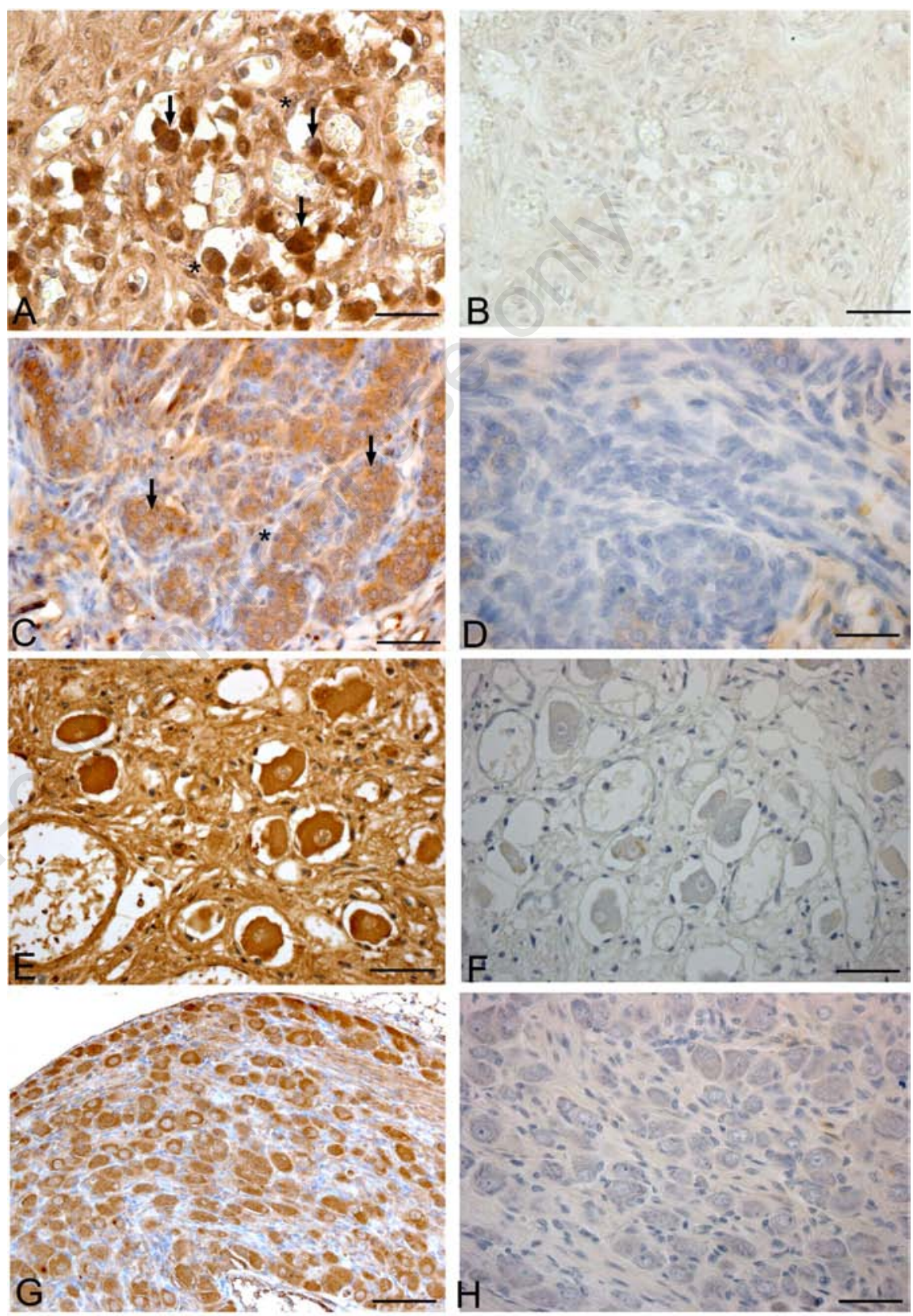

Figure 2. Anti-KISS1R immunohistochemistry in human $(A, B, E, F)$ and rat $(C, D, G, H)$ carotid bodies (A-D) and superior cervical ganglia (E-H), showing selective positivity of glomic type I cells and ganglionic cells, immunostaining being largely eliminated in negative controls (B,D,F,H). Note also negativity of type II cells (asterisks) in the carotid body and of satellite cells in the superior cervical ganglia. Scale bars: A, D, $23.8 \mu \mathrm{m}$; B, C, E, F, 37.5 um; G-H, 75 um. 


\section{References}

1. Lee JH, Miele ME, Hicks DJ, Phillips KK, Trent JM, Weissman BE, et al. KiSS-1, a novel human malignant melanoma metastasis-suppressor gene. J Natl Cancer Inst 1996;88:1731-7.

2. Lee JH, Welch DR. Suppression of metastasis in human breast carcinoma MDA-MB435 cells after transfection with the metastasis suppressor gene, KiSS-1. Cancer Res 1997;57:2384-7.

3. Lee JH, Welch DR. Identification of highly expressed genes in metastasis-suppressed chromosome 6/human malignant melanoma hybrid cells using subtractive hybridization and differential display. Int J Cancer 1997;71:1035-44.

4. Kotani M, Detheux M, Vandenbogaerde A, Communi D, Vanderwinden JM, Le Poul E, et al. The metastasis suppressor gene KiSS1 encodes kisspeptins, the natural ligands of the orphan $\mathrm{G}$ protein-coupled receptor GPR54. J Biol Chem 2001;276:34631-6.

5. Muir AI, Chamberlain L, Elshourbagy NA, Michalovich D, Moore DJ, Calamari A, et al. AXOR12, a novel human G protein-coupled receptor, activated by the peptide KiSS-1. J Biol Chem 2001;276:28969-75.

6. Ohtaki T, Shintani Y, Honda S, Matsumoto $\mathrm{H}$, Hori A, Kanehashi K, et al. Metastasis suppressor gene KiSS-1 encodes peptide ligand of a G-protein-coupled receptor. Nature 2001;411:613-7.

7. Gottsch ML, Clifton DK, Steiner RA. From KISS1 to kisspeptins: An historical perspective and suggested nomenclature. Peptides 2009;30:4-9.

8. Lee DK, Nguyen T, O'Neill GP, Cheng R, Liu $\mathrm{Y}$, Howard $\mathrm{AD}$, et al. Discovery of a receptor related to the galanin receptors. FEBS Lett 1999;446:103-7.

9. Clements MK, McDonald TP, Wang R, Xie G, O'Dowd BF, George SR, et al. FMRFamiderelated neuropeptides are agonists of the orphan G-protein-coupled receptor GPR54. Biochem Biophys Res Commun 2001;284: 1189-93.

10. Mead EJ, Maguire JJ, Kuc RE, Davenport AP. Kisspeptins: a multifunctional peptide system with a role in reproduction, cancer and the cardiovascular system. Br J Pharmacol 2007;151:1143-53.

11. Richard N, Galmiche G, Corvaisier S, Caraty A, Kottler ML. KiSS-1 and GPR54 genes are co-expressed in rat gonadotrophs and differentially regulated in vivo by oestradiol and gonadotrophin-releasing hormone. J Neuroendocrinol 2008;20:381-93.

12. Mi WL, Mao-Ying QL, Liu Q, Wang XW, Li X, Wang $Y Q$, et al. The distribution of kisspeptin and its receptor GPR54 in rat dorsal root ganglion and up-regulation of its expression after CFA injection. Brain Res Bull 2009;78:254-60.

13. Iturriaga R, Alcayaga J. Neurotransmission in the carotid body: transmitters and modulators between glomus cells and petrosal ganglion nerve terminals. Brain Res Brain Res Rev 2004;47:46-53.

14. Nurse CA. Neurotransmission and neuromodulation in the chemosensory carotid body. Auton Neurosci 2005;120:1-9.

15. Porzionato A, Macchi V, Parenti A, De Caro R. Trophic factors in the carotid body. Int Rev Cell Mol Biol 2008;269:1-58.

16. Porzionato A, Macchi V, Amagliani A, Castagliuolo I, Parenti A, De Caro R. Neurotensin receptor 1 immunoreactivity in the peripheral ganglia and carotid body. Eur J Histochem 2009;53:135-42.

17. Porzionato A, Macchi V, Barzon L, Masi G, Belloni A, Parenti A, et al. Expression and distribution of galanin receptor subtypes in the rat carotid body. Mol Med Rep 2010;3:3742.

18. Pardal R, Ortega-Sáenz P, Durán R, LópezBarneo J. Glia-like stem cells sustain physiologic neurogenesis in the adult mammalian carotid body. Cell 2007;131:364-77.

19. Porzionato A, Rucinski M, Macchi V, Stecco C, Castagliuolo I, Malendowicz LK, et al. Expression of leptin and leptin receptor isoforms in the rat and human carotid body. Brain Res 2011;1385:56-67.

20. Porzionato A, Macchi V, Sandra Belloni A, Parenti A, De Caro R. Adrenomedullin immunoreactivity in the human carotid body. Peptides 2006;27:69-73.

21. Arai AC, Xia YF, Suzuki E, Kessler M, Civelli 0, Nothacker HP. Cancer metastasis-suppressing peptide metastin upregulates excitatory synaptic transmission in hippocampal dentate granule cells. J Neurophysiol 2005;94:3648-52.

22. Richard N, Corvaisier S, Camacho E, Kottler ML. KiSS-1 and GPR54 at the pituitary level: overview and recent insights. Peptides 2009;30:123-9.

23. Silvestre RA, Egido EM, Hernández R, Marco J. Kisspeptin-13 inhibits insulin secretion without affecting glucagon or somatostatin release: study in the perfused rat pancreas. J Endocrinol 2008;196:283-90.

24. Vikman J, Ahrén B. Inhibitory effect of kisspeptins on insulin secretion from isolated mouse islets. Diabetes Obes Metab 2009;11Suppl 4:197-201.

25. Daly MB, Lambertsen CJ, Schweitzer A. Observations on the volume of blood flow and oxygen utilization of the carotid body in the cat. J Physiol 1954;125:67-89.

26. Barnett S, Mulligan E, Wagerle LC, Lahiri S. Measurement of carotid body blood flow in cats by use of radioactive microspheres. $\mathrm{J}$
Appl Physiol 1988;65:2484-9.

27. Joels N, Neil E. The excitation mechanisms of the carotid body. Br Med Bull 1963;19:214.

28. Kirby GC, McQueen DS. Effects of the antagonists MDL 7222 and ketanserin on responses of cat carotid body chemoreceptors to 5-hydroxytryptamine. Br J Pharmacol 1984;83:259-69.

29. Di Giulio C, Di Muzio M, Sabatino G, Spoletini L, Amicarelli F, Di Ilio C, et al. Effect of chronic hyperoxia on young and old rat carotid body ultrastructure. Exp Gerontol 1998;33:319-29.

30. Porzionato A, Macchi V, Parenti A, Matturri L, De Caro R. Peripheral chemoreceptors: postnatal development and cytochemical findings in Sudden Infant Death Syndrome. Histol Histopathol 2008;23:351-65.

31. Porzionato A, Macchi V, Guidolin D, Parenti A, Ferrara SD, De Caro R. Histopathology of carotid body in heroin addiction. Possible chemosensitive impairment. Histopathology 2005;46:296-306.

32. Porzionato A, Macchi V, Parenti A, De Caro R. Chronic carotid glomitis in heroin addiction. Histol Histopathol 2009;24:707-15.

33. Porzionato A, Macchi V, De Caro R. Sudden Infant Death Syndrome. N Engl J Med 2009; 361:2580.

34. Di Giulio C, Verratti V, Artese L, Petruccelli G, Walski M, Pokorski M. Aging and expression of heme oxygenase-1 and endothelin-1 in the rat carotid body after chronic hypoxia. J Physiol Pharmacol 2009;60 Suppl 5:414.

35. Prabhakar NR, Jacono FJ. Cellular and molecular mechanisms associated with carotid body adaptations to chronic hypoxia. High Alt Med Biol 2005;6:112-20.

36. Powell FL. The influence of chronic hypoxia upon chemoreception. Respir Physiol Neurobiol 2007;157:154-61.

37. Prabhakar NR, Peng YJ, Kumar GK, Nanduri J, Di Giulio C, Lahiri S. Long-term regulation of carotid body function: acclimatization and adaptation. Adv Exp Med Biol 2009;648:307-17.

38. Arai AC, Orwig N. Factors that regulate KiSS1 gene expression in the hippocampus. Brain Res 2008;1243:10-8.

39. Brady R, Zaidi SIA, Mayer C, Katz DM. BDNF is a target-derived survival factor for arterial baroreceptor and chemoafferent primary sensory neurons. J Neurosci 1999; 19:2131-42.

40. Izal-Azcárate A, Belzunegui S, Sebastián WS, Garrido-Gil P, Vázquez-Claverie M, López B, et al. Immunohistochemical characterization of the rat carotid body. Respir Physiol Neurobiol 2008;161:95-9. 